\title{
Research on the Countermeasures to Promote Yimeng Spirit Influence under Diversified Communication Mode
}

\author{
Hu Chenchen ${ }^{1, a, *}$ \\ ${ }^{1}$ Zaozhuang University,Zaozhuang, Shandong Province, China \\ a304704808@qq.com \\ *corresponding author
}

Keywords: Yimeng spirit; diversification; communication mode; red culture; influence

\begin{abstract}
The Yimeng region has a splendid red culture and a glorious revolutionary tradition. The Yimeng spirit was born in the Yimeng culture. In the new era, diversified modes of communication have become an important vehicle for enhancing the spiritual influence of Yimeng. The dissemination of the Yimeng spirit needs to be guided and supervised by the government departments. It should be based on the children's picture book enlightenment, encourage diversified modes of communication, constantly learn new communication concepts, and tell the story of Yimeng red culture from diversity angles, meanwhile increase the dissemination of infrastructure and capital investment, improve laws and regulations, and effectively improve the influence of Yimeng spirit.
\end{abstract}

\section{Introduction}

With the development of society, the information has become more and more open. The new media have influenced people's attitudes to life to a certain extent, and changed the mode of transmission and existence of the Yimeng spirit, from early interpersonal communication to mass communication. From one-way communication to multi-directional communication, from the private to the international, from the dissemination of the target audience to the dissemination of the audience, so that more people understand, familiar with and love the Yimeng culture, highly promoted the spirit of Yimeng. At present, the mode of communication of the Yimeng spirit is mainly human communication, mass communication, new media, and other modes of dissemination. In the future, it can be involved in the pattern of local children's picture-based mode of communication, so that the mode of development to diversification.

In general, the communication mode of Yimeng red culture today is more advantageous, more convenient, and faster than the traditional model. However, from an objective perspective, this communication process still has different problems. In the model, there are some problems such as the relative lack of penetration, the boring form, and the insufficient content. In the process of dissemination, there are misunderstandings such as the public's low spiritual identification, lack of attraction, lack of funds, over-reliance on the traditional model, and incomplete network dissemination laws and regulations. By mastering the above-mentioned problems, we need to make more precise directions and reasonable suggestions.

\section{Focus on mining picture book of the mode of transmission, increase awareness and understanding of children Yimeng spirit}

Painter creators often convey thoughts and intentions with rich image information. If readers are reading picture books, they can develop rich imagination and thinking from the perception of images, combine living experiences, and summon relevant thoughts to respond to image information. Reading can develop from outside to inside and become mental activities. At present, reading has become an integral part of children's mental development. To promote red culture, the compilation and publication of children's picture books is a good mode of communication. The 
children's picture book integrates visual elements such as text, color, composition, and images, describes a complete and vivid story, and can create children's books with imagination. Its uniqueness and interestingness make many scholars believe that children's picture books are suitable not only for children but also for adults. Therefore, the spread of a wide audience formed a reading for all citizens. Parent-children read together, taste together, share heritage, and innovate. Focusing on excavating the epiphany in the spirit of Yimeng, it is possible to spread the red culture and national spirit of Yimeng, strengthen the ideological and moral construction of young people, promote the economic and political development of the old revolutionary districts of Yimeng, help the development of domestic children's picture books, and facilitate the efficient dissemination of Yimeng spirits, enhance the influence of Yimeng spirit.

The study of integrating the spirit of Yimeng into children's picture books points the way for children's ideological education. Although 3-6 years old children have little literacy ability, they have a strong ability to recognize graphics and colors. Picture book creators can try to draw important plot clues. Local objects can be imagined by children through parents or education. The correct guidance of children can enable children to interpret the illustration images in the picture book, win the children's favor and interest, meet the children's needs for listening and appreciation, create a warm, patriotic environment, and deepen the construction of the visual sense of the picture and the inner spirit. The interesting story will stimulate children's patriotic feelings and imagination, so that the child's brain forms a complete and coherent unique artistic form with national spirit.

The localization of the picture book content and theme is the advantage of picture-based communication. We must deepen the psychological needs of readers and build an effective picture book design program. Picture books are intangible in helping children learn aesthetics, and to a certain extent they have fulfilled the need for aesthetic education. Through an interesting and lively picture-based communication and reception, the international language model is used to describe the Yimeng story in a micro-narrative manner, expand the Yimeng spirit's dissemination channels, and expand Yimeng spirit's influence. The realization of the revolutionary culture represented by the spirit of Yimeng is widely spread in children's education. In this way, children's understanding of Chinese traditional culture can be enhanced, and the public's awareness of the subject can be stimulated to enable people to establish a correct outlook on life and values. At the same time, the spiritual communication of Yimeng spirit can bring great opportunities for the development of original domestic picture books.

\section{Encourage diversity modes of communication and encourage public participation consciousness}

In the red tourism area, the reproduction of red stories is mainly based on interpersonal communication and mass communication, which has the limitation of time and space. Need to introduce elements of new media to assist in the completion of diversified communication. For example, in the interpersonal communication, it involves new media platforms such as recording, live broadcasting, and push, and operates through diversity modes such as network, podcasting, microblog, television, and newspapers, so as to give full play to the strength of the public, expand the propaganda channels of Yimeng culture, and promote publicity. The content of the red culture, everyone strives to become a red cultural disseminator, can truly break the limitations of a single dissemination, forming a diversified network of transmission pattern.

In the exploration of the dissemination route, try the government propaganda department to establish an official Weibo, WeChat, regularly update the dynamic information of the relevant Yimeng red culture, and take full advantage of the subjective initiative of the public, so that the personal experience, old comrades, relatives and other public participate in Yimeng In the interaction and discussion of red culture, encourage the public to actively and effectively spread. In the traditional red cultural live broadcast program, the "Yimeng red cultural room" is set up. The public is asked to collect red stories from the public in the old Yimeng district. The most persuasive person in the revolutionary war years can be selected, and distinguished representatives from different occupations in the Yimeng region are selected to serve guests. "Cultural intercourse" 
enables the general public to recognize, feel and understand the red culture, interpret the Yimeng red culture, put forward reasonable suggestions, promote the positive energy of the society, encourage the public's sense of participation to carry out red cultural dissemination, and be conducive to the diversified network communication pattern. The formation of the effective way to enhance the influence of Yimeng spirit.

\section{Respect the objective facts, active and innovative cultural content, story red building in a unique perspective about the spread of micro}

In the scene of the red cultural site, the guide passes the red cultural content information to the public, but the content appears relatively fixed, lacks a unique perspective and new content, so that the public can not understand and access valid information for the scenic spot for many times, receiving cultural information. It is difficult to form effective interaction, and the sense of identity of the spiritual concept of the red culture will also be weakened. In the traditional mass media, the subjects are mostly red cultural narratives, television dramas, movies, and promotional videos from the same perspective, and the contents are updated slowly. Under the new media communication model, it is necessary to make full use of the Internet media to spread the value and meaning of "Yimeng Spirit" in a more vivid form, inspire the public's sense of participation in the main body, and enable the Yimeng red culture to form wider spread.

\subsection{To ensure the objective truthfulness of Yimeng story in the process of diversified communication}

The description of the red story is mainly based on historical facts. Through the portrayal and shaping of characters' deeds and characters, the spirit of red culture is highlighted. In the construction of stories, there are often "old" and "old-fashioned" problems. The narrative patterns are stylized, the character descriptions are too idealistic, and even the objective reality is not met. The general public's sense of identity in the stereotyped story is weakened, and the degree of attention is also followed decline. Under the diversified communication environment, establish the initiative of public communication, improve the public's ability to cognize and criticize information, and cultivate objective awareness of communication. The construction of the "red story" should respect facts, not forge, and not be false. It promotes the spirit of Yimeng from an objective perspective, thus infecting the public to achieve the sublimation of art.

\subsection{A unique perspective on red stories, focusing on the value and significance of red stories}

In order to make the "Red Story" more artistic and infectious, it is necessary to break the traditional narrative mode of view, view the story from different perspectives, change the way of thinking, diverge thinking, and actively seek more unique and suitable for "red story" micro Tell the pattern. Make more people understand and understand Yimeng culture. For example, the story of "Yimen Hongsao" must be familiar to everyone. It is a moving story of deaf and mute person Mingde Ying who used latex to rescue soldiers. According to statistics, the narrative perspective of the story is basically described from a macro perspective, with the development of the revolutionary war as the main line, and "Hongsao" milk to save people as a factual basis and to represent the noble quality of "Hongsao". Which delivered a moving storyline. After thinking from a macro perspective, the creator can also tell the story from a micro perspective. For example, the family background of Hongsao, her personal character, and the psychological description of saving her life can be cut into the story of the picture book and achieve the spirit of dissemination. The broadening of the public has promoted the public's sense of identity and influence in the spirit of Yimeng.

\section{Give Play to the Advantages of New Media Communication and Construct a Virtuous Circular Communication Model}

In the dissemination of Yimeng red culture, the public is often more interested in the mode of communication of Yimeng culture. This makes Yimeng's spiritual communication audience limited. 
Such as the dissemination of audience objects, is not conducive to the feedback and interaction of effective information. It is no longer able to adapt to the development and needs of the era of public communication. Next, the main body of communication must fully respect the public's ideas and cognitive laws. In the diversity modes of communication, each individual has the right to publish public opinions and speak out their own ideas. The principle of equality, trust, and mutual interaction between the subject and the public is disseminated, and a mutually beneficial benign circular communication model is established with the public. Of course, this also requires supervision and restriction and management of relevant laws and regulations.

\section{Improve laws and regulations, increase capital and cultural facilities into the red propaganda, effectively boost the spread of influence of the Spirits}

In the process of dissemination, Yimeng spirit has a shortage of funds and technical scarcity. Because individual groups do not have a deep understanding of the red culture and cannot find a red culture's significance for the development of the country from a unique perspective, the funds invested in red culture are relatively small. Some media are more involved in the promotion of foreign entertainment culture. This is a question that everyone needs to ponder. If you want to fundamentally improve the influence of Yimeng's spiritual spread, you need to invest in funds and technology in all aspects of the dissemination process.

\subsection{Encourage the diversity of funding sources}

In the process of Yimeng's spiritual communication, more traditional ways of relying on government support should be changed. Enterprises, social organizations, and other organizations should be encouraged to participate in the dissemination of Yimeng red culture and encourage the diversity of funding sources. Yimeng cultural institutions and non-profit organizations or enterprises unite through diverse transmission media to promote the goal of mutual benefit and winwin between the spiritual and cultural connotations of Yimeng. In addition, enterprises and organizations invest in red cultural transmission funds. On the one hand, it can also enhance its own image and popularity, and it plays a very good boosting role in the development of the market economy.

\subsection{Strengthen personnel training to improve technology and increase investment in infrastructure spread}

In the new era of public communication, the innovative elements at the forefront of science and technology have made rapid progress in all relevant fields of society. In addition to the improvement of the infrastructure of new media, it is also necessary to cultivate relevant technical professionals for the dissemination of Yimeng culture so that they can master the media's dissemination. The application of knowledge will better serve the dissemination of the Yimeng red culture service, and it will enable the rapid resolution of technical problems in the process of dissemination, screening and filtering out unhealthy public opinions, ensuring that the Yimeng spirit will develop in a healthy and steady manner in the new era, and making Yimeng red. Cultural communication is more efficient and convenient.

\subsection{Continue to improve the sound laws and regulations concerning the dissemination of red culture, and improve the long-term mechanism for the extensive influence of Yimeng spirit}

At present, China's laws and regulations on public communication have become increasingly perfect. There are certain safety norms and measures in the process of media dissemination, but there are still some problems that need continuous improvement and improvement.

First of all, for communicators to adhere to the moral consciousness, correctly propagate the content of the dissemination of themes, not fabricated, no exaggeration, and objectively evaluate the facts. The policies promulgated by the government departments have restrictions on the communicators, which leads to the formation of an equal, trusting, and healthy relationship between the propagating subject and the object. 
Second, to improve the legal system and laws and regulations, all government departments have their own responsibilities, and strengthen communication and contacts. They do not shirk and do not slack off. Some problems that may arise during the dissemination process are foreseen, and corresponding solutions are available. Avoid contradictions and conflicts.

Finally, new legal policies are formulated in time for problems. In order to achieve a significant increase in the influence of Yimeng spirit. Relevant government departments must increase their participation so that Yimeng culture can be correctly guided and supervised in the dissemination process. Grasp the development laws and characteristics of diversified media communications, regulate themselves from the perspective of laws and regulations, and avoid problems such as low communication efficiency and the dissemination of negative content in the dissemination process.

"Love the party, love the army, forge ahead with courage, start business with arduous efforts, and selfless dedication" profoundly demonstrate the noble quality and cultural connotation of Yimeng people in the revolutionary era. In the era of public communication, we should reconstruct the space-time concept of Yimeng red culture. Enhancing the spiritual influence of Yimeng requires us to re-examine the new modes of communication and effective ways to solve such problems. From a long-term perspective, the dissemination of Yimeng spirit needs to be guided and supervised by government departments, and the enlightenment of children's picture books should be the breakthrough point. Encourage diversified modes of communication, constantly drawing on new communication concepts, telling red cultural stories from diversity angles, perfecting laws and regulations, increasing capital investment in disseminating infrastructure, and enhancing the influence of Yimeng spirit.

\section{Acknowledgements}

Shandong Province Social Science Planning Project "heritage and development of Spirits in children's picture books in the" project number: (18CYMJ38) initial results.

Shandong Province Science and Art 2018 Key Issues "underlying trend in the development of research at regional earthenware Cultural Perspective" initial results.

2018 annual Shandong Province, employment and entrepreneurship research topic: "Students explore innovation and entrepreneurship education and practice of non-industrial cultural heritage sight" (18SYB087) initial results.

\section{References}

[1] Xu Dongsheng, Sun Haiying. Yimeng Spirit College Student Reader. Shandong People's Publishing House, November 2016.

[2] Tu Keguo. On the relationship between Yimeng spirit and Linyi culture [J] .Journal of Linyi Normal University, 2004, (10): 0-13.

[3] Wang Yihong. On the Definition and Definition of "Interpersonal Communication"[J]. Journalism and Communication Studies, 2015, 22(07):112-125..

[4] Qin Yan, The rise of new media and the management strategy of traditional media [J], Economic Research Guide, 2011, 127(17): 287-289.

[5] Li Fengming. Visual Elements and Spatial Study of Children's Picture Book [D]. Qingdao Technological University, 2013.

[6] Yang Jinjuan. Research on Yimeng Spiritual Characteristics in the Branding of Yimeng Culture in the New Era[J].Journal of Linyi University,2017,39(01):1-8.

[7] Zheng Xiaodi. Thinking of promoting the efficiency and pertinence of the red culture dissemination of Yimeng[J]. China Press, 2017(17):80-81.

[8] Duan Hao. Research on the Influence of Promoting Shanxi's Red Culture in the New Media Age [D]. Taiyuan University of Technology, 2017. 
[9] Qin Guoyang, Deng Xiaoming. The spread of red culture in Yimeng and Mongolia in the era of new media[J]. Young Journalist, 2017(23): 65-66.

[10] Wang Mengyao. Inheritance and Development of Yimeng Folk Culture in the Transformation of Communication Mode[J]. Humanities and World, 2016(03):54-58.

[11] Li Aijuan. Yi-Ming Red Culture Communication and Path Selection Based on Network Innovation Environment[J].Shandong Social Sciences,2012(06):154-156. 